\title{
Subsidence of the Vøring Basin and the influence of the Atlantic continental margin
}

\author{
ALAN M. ROBERTS ${ }^{1}$, ERIK R. LUNDIN ${ }^{2}$ \& NICK J. KUSZNIR ${ }^{3}$ \\ ${ }^{1}$ Badley Earth Sciences Ltd, North Beck House, North Beck Lane, Hundleby, Spilsby, Lincs PE23 5NB, UK \\ (e-mail: alan@badleys.co.uk) \\ ${ }^{2}$ Statoil Research Centre, Postuttak, N-7005 Trondheim, Norway \\ ${ }^{3}$ Dept. of Earth Sciences, University of Liverpool, PO Box 147, Liverpool L69 3BX, UK
}

\begin{abstract}
The post-Cretaceous subsidence history of the Vøring Basin, part of the Atlantic passive margin offshore mid-Norway, has been investigated. Extension and $\beta$-factors related to rifting and continental break-up during the Palaeocene have been quantified using both forward and reverse basin-modelling techniques. In the preferred geological model it is assumed that rifting occurred in the Vøring Basin during the Palaeocene (prior to break-up), following an earlier rift event during the Late Jurassic. During Palaeocene rifting the basin may have been dynamically uplifted by the Iceland mantle plume. In the east of the basin there was no Palaeocene extension. Subsidence analysis shows that in the centre of the basin forward and reverse models converge to predict a modest Palaeocene stretching factor $(\beta)$ of $c$. 1.15. In the west of the basin, closest to the Atlantic margin, forward models of upper-crustal faulting also predict a $\beta$ of $c .1 .15$, but reverse (backstripped) models of subsidence predict a $\beta$ of up to 1.75 . We suggest that lower-crustal and mantle-lithosphere thinning close to the margin were greater than the extension accommodated by upper-crustal faulting and that some lower-crustal/mantle-lithosphere stretching associated with continental separation was partitioned below the Vøring Basin, up to $150 \mathrm{~km}$ landwards of the margin.
\end{abstract}

Keywords: Norway, Atlantic Ocean, Palaeocene, models, rifting.

Our understanding of the geodynamics of rift basins has been greatly increased by the application of quantitative models, capable of studying basin development in either the forward or reverse sense (e.g. McKenzie 1978; Kusznir \& Egan 1989; Weissel \& Karner 1989; Marsden et al. 1990; Kusznir et al. 1991, 1995; Young 1992; Roberts et al. 1993; Watts \& Torné 1992; Nadin \& Kusznir 1995). Much of the European work on rift basins has been driven by hydrocarbon exploration in the major Mesozoic rifts of NW Europe. As exploration has proceeded commercial attention has shifted westwards from true intra-continental rifts (the North Sea being the prime example) to the Atlantic passive continental margin and its associated sedimentary basins. In this paper we apply forward and reverse basin-modelling techniques to the Vøring Basin, an area close to the Atlantic margin in mid-Norway. From the results of the modelling we draw some conclusions about the geological history of the Vøring Basin and the possible nature and distribution of lithospheric stretching during continental break-up.

\section{The Vøring Basin}

The Vøring Basin lies off the west coast of Mid-Norway (c. $\left.66-68^{\circ} \mathrm{N}\right)$. It lies between the well-explored Halten Terrace petroleum province to the east and the Atlantic continental margin to the west (Fig. 1). To date only two exploration wells exist in the basin, both close to the eastern margin (Fig. 1). Major parts of the basin have recently been licensed for future exploration.

The geological, and particularly the tectonic, history of the basin has been well summarized by Skogseid et al. (1992a, b) and Skogseid (1994), to which readers are referred for background information. Our own analysis of the Vøring Basin confirms earlier interpretations that it has a compound and complex extensional history. The youngest and most prominent extensional structures in the basin are of Palaeocene age (c. $65 \mathrm{Ma}$ ), immediately predating continental break-up west of the basin at around the Palaeocene-Eocene boundary (57.5 Ma, Skogseid et al. 1992a). These youngest faults are superimposed on older, more poorly imaged, structures of Jurassic and/or Cretaceous age. Direct analogy with the Halten Terrace area (Fig. 1) suggests a Late Jurassic age. The studies of Skogseid et al. (1992a, b) and Walker et al. (1997) have used a Late Jurassic age for the earlier structures, but Lundin \& Doré (1997) have suggested an alternative tectonic model with greater emphasis on Cretaceous extension. Both the Palaeocene and earlier rift events are accounted for in our models. The Halten Terrace analogy would suggest that older (Permo-Triassic) structures may also exist, but these are not resolved by current seismic data. Seismic data can image structural information to within $c .50 \mathrm{~km}$ of the continental margin. In the westernmost $50 \mathrm{~km}$ of the basin, however, (across the Vøring Marginal High, Fig. 1) basalts associated with break-up mask the underlying structure.

\section{Modelling techniques}

In this paper we use the flexural cantilever model for forward modelling rift structure, and flexural backstripping (incorporating thermal subsidence modelling) for reverse modelling subsidence history. Both techniques have been extensively documented elsewhere (e.g. Kusznir et al. 1991, 1995; Kusznir \& Ziegler 1992; Roberts et al. 1993) and are not described in detail here.

The flexural cantilever model is used to develop forward models of the syn-rift and post-rift structure and stratigraphy 


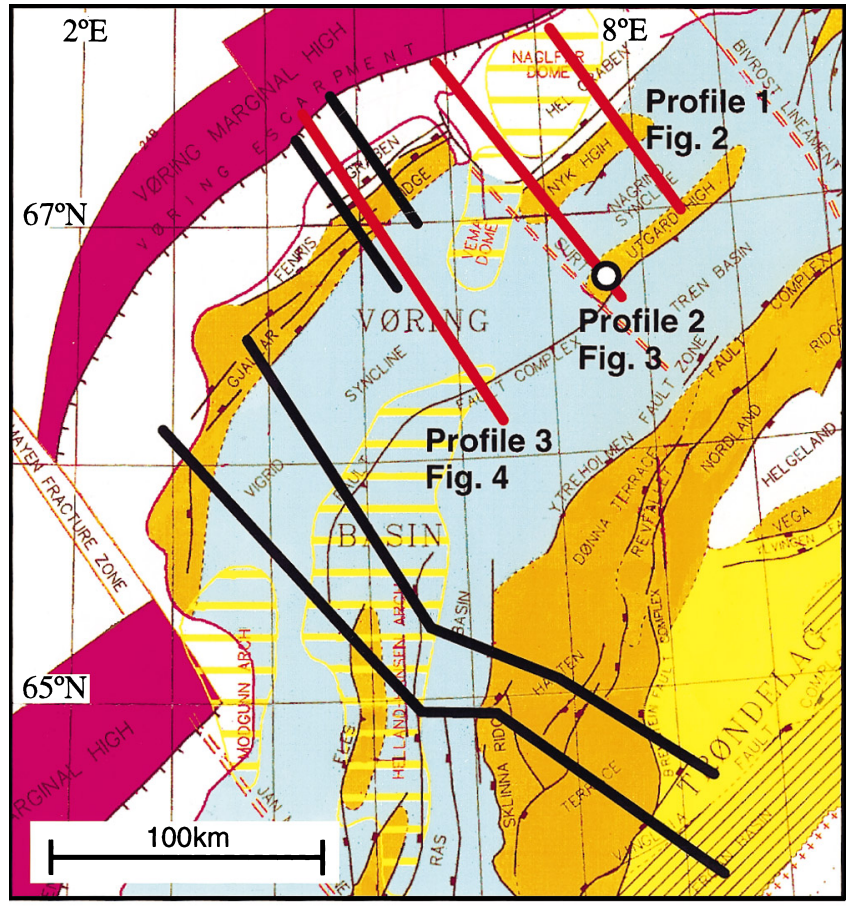

Profiles evaluated here for Palaeocene extension

Fig. 1. Structural elements of the Vøring Basin and the location of the seven profiles modelled during this study. The three profiles discussed here are highlighted in red. The circle on Profile 2 shows the location of wells 6607/5-1 \& 2. (See Walker et al. 1997, fig. 1 and Lundin \& Doré 1997, fig. 1 for the regional setting of the Vøring Basin.)

of cross-sections through a rift basin (e.g. Nadin \& Kusznir 1995). The model incorporates flexural isostasy, compaction, sediment loading, erosion and thermal perturbation of the lithosphere. It is used to make estimates of lithosphere extension, $\beta$-factor, footwall uplift, amounts of erosion, and rift-related heat-flow.

Flexural backstripping takes a present-day cross-section and progressively removes stratigraphic units to restore the basin's post-rift structural and stratigraphic geometries. This modelling technique incorporates flexural isostasy and reverse thermal subsidence modelling, in addition to sediment unloading and decompaction. It is constrained by using known palaeobathymetric markers. It is used to predict palaeobathymetry/ topography, depositional slopes and to estimate $\beta$ independent of fault-block structure. The limitations of Airy backstripping and the advantages of reverse post-rift modelling using flexural backstripping have been discussed by Kusznir et al. (1995) and Nadin \& Kusznir (1996).

While both forward and reverse modelling techniques can be used independently their full potential lies in using them in combination (e.g. Roberts et al. 1993, 1995; Kusznir et al. 1995; Nadin \& Kusznir 1995). In the models described here a number of common input parameters have been applied. All incorporate long-term eustasy, using the data of Haq et al. (1987) and the time-scale of Harland et al. (1990). The effective elastic thickness $\left(T_{\mathrm{e}}\right)$ of all models (used to control the flexural isostatic response) is $1.5 \mathrm{~km}$, although sensitivity to small (but finite) values of $T_{\mathrm{e}}$ is not great because the post-rift loads removed during backstripping are generally of long wavelength. Sensitivity studies of footwall-uplift radius yield $T_{\mathrm{e}}$ of $1.5 \mathrm{~km}$ to be the most suitable for forward modelling. The youngest rift event is always set at $65 \mathrm{Ma}$ (CretaceousPalaeocene boundary). Three lines are described, forming part of a larger regional study. The stratigraphy and decompaction parameters used are listed in Table 1 .

\section{Model results}

\section{Profile 1}

Profile 1 extends from the Nyk High to the edge of the Vøring Marginal High (Fig. 1). Figure 2a shows a present-day depth section of this profile, vertically exaggerated for clarity. Note the water depth is everywhere $>1 \mathrm{~km}$. The major structural feature on this line is the Nyk High, interpreted as an uplifted and eroded footwall, adjacent to a large Palaeocene fault (see Roberts \& Yielding 1991). The regional bevelling of the high and interpreted missing stratigraphic section suggest erosion at or near sea level during the Palaeocene; parts of the Nyk High may also have been eroded later in the Tertiary. We use this structure as a palaeobathymetric marker with which to constrain backstripping (see Kusznir et al. 1995).

Figure $2 b$ shows Profile 1 backstripped to the top Cretaceous-base Tertiary unconformity (65 Ma). The critical feature of this restoration is the eroded Nyk High at sea-level, making the restoration acceptable. There are a number of different model assumptions that will produce this restoration; some are discussed below, but the simplest is to restore the section assuming that thermal subsidence (post-rift and

Table 1. Stratigraphy and decompaction parameters for Profiles 1-3

\begin{tabular}{lcccc}
\hline Layer & $\begin{array}{c}\text { Age of } \\
\text { base } \\
(\mathrm{Ma})\end{array}$ & $\begin{array}{c}\text { Surface } \\
\text { porosity } \\
(\%)\end{array}$ & $\begin{array}{c}\text { Decompaction } \\
\text { constant } \\
\left(\mathrm{km}^{-1}\right)\end{array}$ & $\begin{array}{c}\text { Matrix } \\
\text { density } \\
\left(\mathrm{g} \mathrm{cm}^{-1}\right)\end{array}$ \\
\hline 1, pink & 2 & 61 & 0.48 & 2.70 \\
2, blue & 2.5 & 61 & 0.48 & 2.70 \\
3, yellow & 15 & 63 & 0.51 & 2.72 \\
4, purple & 30 & 63 & 0.51 & 2.72 \\
5, green & 57 & 63 & 0.51 & 2.72 \\
6, red & 65 & 63 & 0.51 & 2.72 \\
7, violet & $85(80)$ & 61 & 0.48 & 2.70 \\
8, grey & $140(110)$ & $56(61)$ & 0.48 & 2.70 \\
9, blue & $250(130)$ & $(56)$ & $(0.39)$ & $2.68(2.70)$ \\
(10, yellow) & $(250)$ & & $(2.68)$ \\
\hline
\end{tabular}

Figures in parentheses refer to Profile 3 where different from 1 and 2. 
a) Present-day cross-section (in depth, $\mathrm{km}$ )

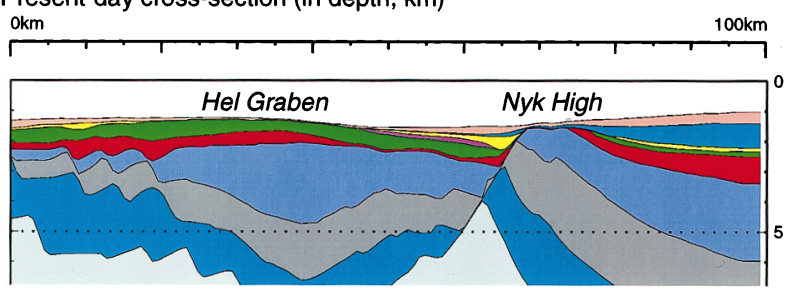

b) Preferred restoration at the base of the Palaeocene

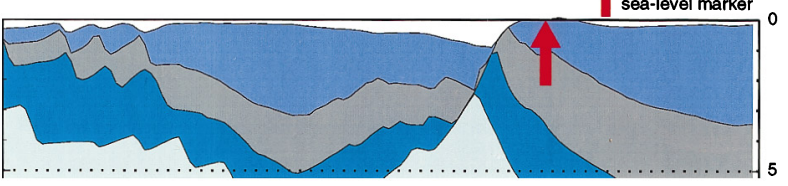

c) Three beta-profiles associated with models of this section

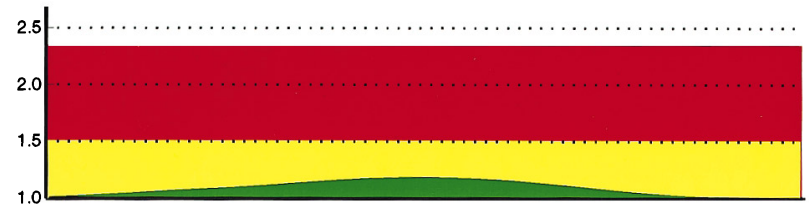

d) Palaeocene syn-rift forward model, compared with template of (b)

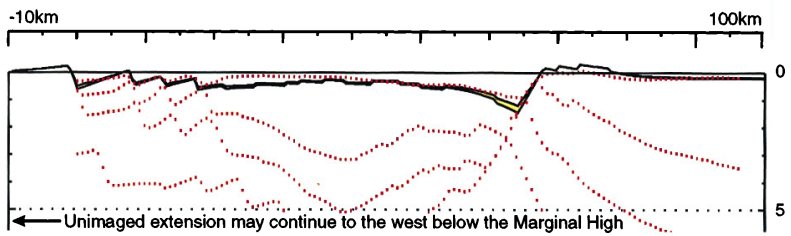

Fig. 2. Profile 1. (a) Present-day cross-section. See Table 1 for details of stratigraphy. (b) The preferred palaeogeographic restoration at the base Palaeocene. The Nyk High is at sea-level. (c) Three Palaeocene $\beta$-profiles. Red is $\beta$ for a Palaeocene-only stretching model. Yellow is $\beta$ incorporating $150 \mathrm{Ma}$ stretching and plume uplift in the model. Green is $\beta$ from the forward model. (d) Forward model, including erosion, of syn-rift upper-crustal structure. The red dots are a template of (b) to which the forward model can be compared.

post-break-up) occurred in response only to Palaeocene stretching at $65 \mathrm{Ma}$. In this case a $\beta$ stretching-factor of 2.35 (Fig. 2c) is required to input sufficient reverse thermal subsidence to restore the Nyk High to sea level. By removing the Palaeocene sequence during backstripping we have removed the thin syn-rift section as well as the full post-rift section. The effect of this will be to overestimate sediment unloading of the basin, giving an underestimate of thermal subsidence and $\beta$.

Figure $2 \mathrm{~d}$ shows a forward model of the faulted structure on this profile, compared with a template of the base-Palaeocene restoration (dotted lines). The match at the model surface is good and we take the forward model as a reliable indicator of fault-controlled extension (see Roberts et al. 1993). The $\beta$-profile derived from the forward model is shown (green) in Fig. 2c. It has a peak value of $c$. 1.2, and is much less than the uniform $\beta$ of 2.35 derived from backstripping. Extension during the Palaeocene rift phase may have continued (unimaged) to the NW, below the lavas of the Marginal High (Fig. 1). The western drop in $\beta$ back to 1 may therefore be an artefact at the edge of the forward model.

Two geological factors may reduce the estimate of Palaeocene $\beta$ derived from backstripping; earlier (JurassicCretaceous) rifting and post-Palaeocene collapse of plume

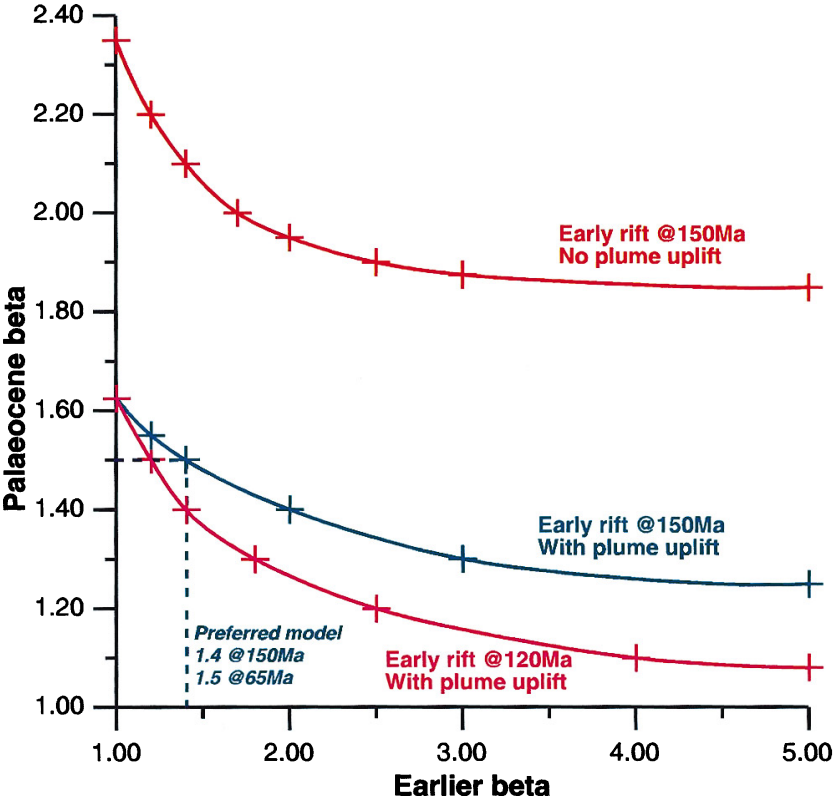

Fig. 3. Plot showing combinations of Palaeocene $\beta$ and earlier-rift $\beta$, for three given assumptions about plume support and earlier rift age, which will produce the acceptable palinspastic restoration in Fig. 2b.

dynamic-uplift. The magnitude of earlier extension has been addressed by forward modelling the Halten Terrace and part of the Rås Basin to the east, using the southern two profiles in Fig. 1. This yields a minimum Late Jurassic $\beta$ of 1.2 for the Vøring Basin. A more likely average would be $c$. 1.4. Maximum Jurassic $\beta$ would be c. 2.0. These figures are in broad agreement with those calculated by Skogseid et al. (1992b). Adopting a constant Jurassic $\beta$ value across the modelled profiles of the Vøring Basin may be an oversimplification, but there is no realistic way of accurately constraining this parameter within most of the basin, and so a single calculated value is chosen.

The buoyant effects of the Iceland Plume during the Palaeocene should also be included (Milton et al. 1990; Nadin \& Kusznir 1995). If the Vøring Basin were dynamically uplifted by the plume during the Palaeocene, with subsequent collapse of this support after continental separation, then some postPalaeocene subsidence would be plume driven and not the result of crustal stretching. We have not incorporated crustalunderplating in our models (see Skogseid et al. 1992a, b and Skogseid 1994 for discussion) as the buoyant effects of underplating would maximize estimates of Palaeocene $\beta$ from backstripping and increase the discrepancy with forward modelling.

On a Palaeocene reconstruction of the North Atlantic (e.g. Skogseid et al. 1992a, fig. 1) the Vøring Basin and the North Viking Graben (North Sea) lie equidistant from the centre of the Iceland Plume (assumed here to be radial in its surface effect). Using a similar backstripping methodology to Nadin \& Kusznir (1995) we have estimated Palaeocene uplift in the North Viking Graben to be $c .460 \mathrm{~m}$. We have therefore incorporated $460 \mathrm{~m}$ of post-Palaeocene subsidence as plumedriven, rather than thermally driven, in our revised model calculations.

There are many combinations of model parameters which will produce the restoration of Fig. 2. Some of these are summarized (Fig. 3) by plotting acceptable combinations of Palaeocene and earlier $\beta$ for three given assumptions about 
plume support and early rift age. The preferred geological model chosen here adopts an older rift age of $150 \mathrm{Ma}$ with $\beta=1.4$ and plume support during the Palaeocene, giving a Palaeocene $\beta$ of 1.5. Moving the rift age to $120 \mathrm{Ma}$ (see Lundin $\&$ Doré 1997) would reduce Palaeocene $\beta$ to 1.4. Figure 3 shows, however, that in terms of assessing Palaeocene $\beta$ earlier rift age is a less important parameter than assuming whether plume support was present or not.

Figure $2 \mathrm{c}$ shows that the preferred Palaeocene $\beta$ from reverse modelling (1.5) is still considerably greater than that obtained by forward modelling (peak at 1.2). The forward and reverse models are therefore not consistent in terms of their implied stretching histories, even though we have ignored the possible uplift effects of underplating and removed the full Palaeocene section during backstripping, thus minimizing our reverse-modelled estimate of $\beta$. If we backstrip Profile 1 using $\beta$ from the forward model (allowing for a $150 \mathrm{Ma} \beta$ of 1.4 and Palaeocene plume support) a Palaeocene bathymetry of $>500 \mathrm{~m}$ remains above the eroded Nyk High (not illustrated) and the model produced is geologically unsatisfactory. Is this an error in the models or an observation repeatable on other data from the Vøring Basin?

\section{Profile 2}

Profile 2 lies $c .55 \mathrm{~km} \mathrm{SW}$ of Profile 1, crossing the same major structural features (Fig. 1). It is a slightly longer profile and extends onto the crest of a prominent structural ridge, the Utgard High (Fig. 4a), penetrated by the only exploration wells currently drilled in the basin (Fig. 1; Walker et al. 1997, fig. 3). Well data show that part of the Upper Cretaceous section is absent below a base Palaeocene unconformity. We interpret this unconformity to result from footwall uplift of the Utgard High during early Palaeocene extension on the adjacent Fles Fault Zone (Fig. 1, Walker et al. 1997, fig. 3). We use the Utgard and Nyk Highs as palaeobathymetric markers to constrain backstripping. Note the current bathymetry varies from $c .500 \mathrm{~m}$ above the Utgard High to $c .1300 \mathrm{~m}$ above the Hel Graben.

Figure $4 \mathrm{~b}$ shows Profile 2 backstripped to the base Tertiary, with the crests of the Nyk and Utgard Highs restored to sea level. This restoration is considered geologically acceptable. Figure $4 \mathrm{c}$ shows the $\beta$-profile required to produce this restoration, assuming a Palaeocene-only rift model. For the Nyk High a constant $\beta$ of 2.35 (the same as for the comparable model of Profile 1, Fig. 2c) is required, while for the Utgard High a $\beta$ of 1.6 is needed. This implies a gradient of $\beta$ decreasing eastwards.

A forward model (not illustrated) for the syn-rift (Palaeocene) structure of Profile 2 (including the Fles Fault Zone) has been constructed. The $\beta$-profile derived from this model is shown (green) in Fig. 4c. Fault-related extension has a maximum $\beta$ of 1.13 , below the Hel Graben. This forward modelled $\beta$-profile is much less than the $\beta$-profile of our most simple backstripped model.

A third $\beta$-profile for Profile 2 is shown in Fig. 4c. It is the Palaeocene $\beta$-profile required to produce the restoration in Fig. $4 \mathrm{~b}$, assuming an earlier $150 \mathrm{Ma}$ rift of $\beta=1.4$ and allowing for $460 \mathrm{~m}$ of plume-driven subsidence (Fig. 3). The $\beta$-profile tapers from 1.5 in the NW to 1.1 below the Utgard High. In the NW the required $\beta$ is still significantly in excess of the forward-modelled $\beta$, but at the Utgard High the required $\beta$ is similar to the forward-modelled $\beta$. The implications of this are a) Present-day cross-section (in depth, $\mathrm{km}$ ) Okm

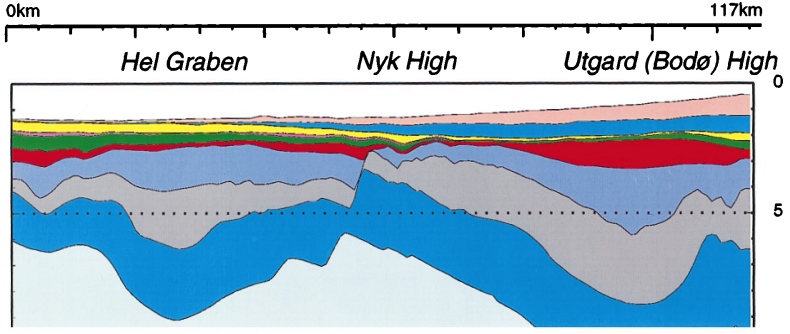

b) Preferred restoration at the base of the Palaeocene

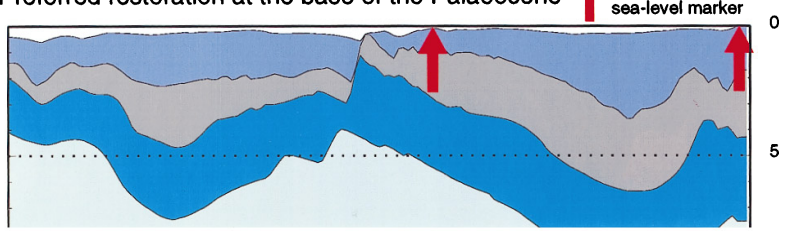

c) Three beta-profiles associated with models of this section

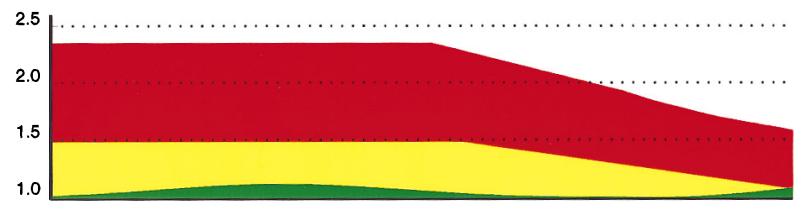

d) Base Palaeocene restoration using beta from forward model

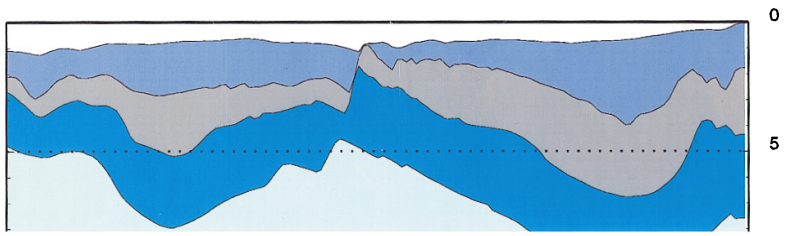

Fig. 4. Profile 2. (a) Present-day cross-section. See Table 1 for details of stratigraphy. (b) The preferred palaeogeographic restoration at the base Palaeocene. The Nyk and Utgard Highs are at sea-level. (c) Three Palaeocene $\beta$-profiles. Red is $\beta$ for a Palaeocene-only stretching model. Yellow is $\beta$ incorporating $150 \mathrm{Ma}$ stretching and plume uplift in the model. Green is $\beta$ from a forward model. (d) Base Palaeocene restoration using $\beta$ from forward model (green in c). The Utgard High is at sea-level but the Nyk High is submerged.

shown in Fig. 4d, where Profile 2 is backstripped to base Palaeocene using $\beta$ from the forward model, assuming a $150 \mathrm{Ma}$ rift $(\beta=1.4)$ and plume-driven subsidence. The Utgard High is restored to sea level, but there is nearly $1 \mathrm{~km}$ of bathymetry above the Nyk High. We thus make the observation that in the SE of the profile the preferred forward and reverse models can be reconciled with a common value of $\beta$, but in the NW (nearer to the continental margin) $\beta$ required for backstripping is significantly greater than $\beta$ defined by upper-crustal extension. Can this observation be repeated on another profile?

\section{Profile 3}

Profile 3 lies $c .75 \mathrm{~km} \mathrm{SW}$ of Profile 2 (Fig. 1). It is the longest of the three profiles $(175 \mathrm{~km})$. It starts in the $\mathrm{NNW}$ on the lava-capped Vøring Marginal High, extending across the Gjallar Ridge, the Fles Fault Zone and into the Rås Basin (Fig. 5a). The Gjallar Ridge (seismic data in Lundin \& Doré 1997, fig. 5) is a series of tilted and eroded Palaeocene fault blocks, similar to the Nyk High on Profiles 1 and 2. Three 
a) Present-day cross-section (in depth, $\mathrm{km}$ )

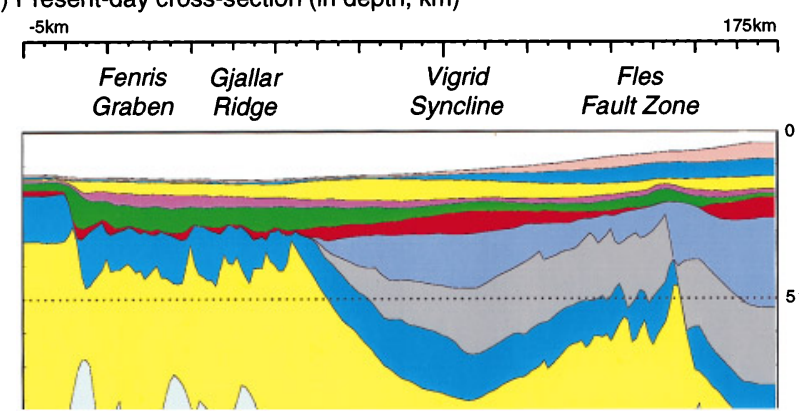

b) Preferred restoration at the base of the Palaeocene

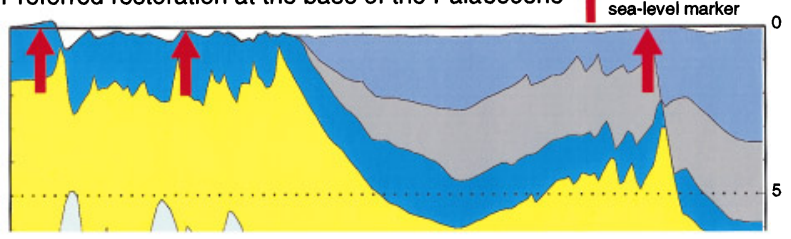

c) Three beta-profiles associated with models of this section

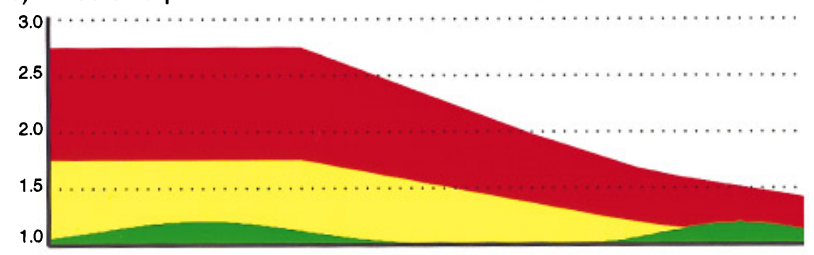

d) Base Palaeocene restoration using beta from forward model

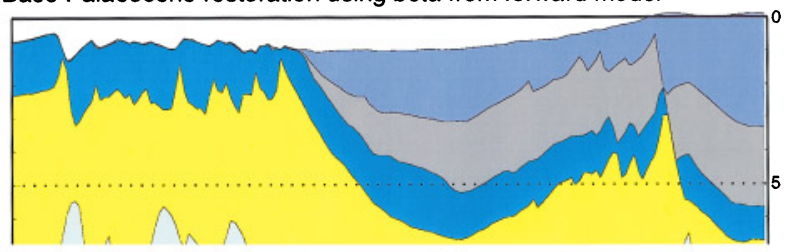

Fig. 5. Profile 3. (a) Present-day cross-section. See Table 1 for details of stratigraphy. (b) The preferred palaeogeographic restoration at the base Palaeocene. The Vøring Marginal High, the Gjallar Ridge and the Fles Fault Zone are close to sea-level. (c) Three Palaeocene $\beta$-profiles. Red is $\beta$ for a Palaeocene-only stretching model. Yellow is $\beta$ incorporating $150 \mathrm{Ma}$ stretching and plume uplift in the model. Green is $\beta$ from a forward model. (d) Base Palaeocene restoration using $\beta$ from forward model (green in c). The Fles fault Zone is at sea-level but the Gjallar Ridge is submerged.

possible Palaeocene sea-level markers lie on this profile, the Vøring Marginal High (the frontal escarpment to which we interpret as a major fault), the eroded footwalls of the Gjallar Ridge and the footwall of the Fles Fault Zone (along strike from the Utgard High, Profile 2). We aim to restore these structures to sea-level in our preferred restoration. Current bathymetry across the profile ranges from $c .400 \mathrm{~m}$ above the Rås Basin to $c .1300 \mathrm{~m}$ above the Marginal High.

Figure $5 \mathrm{~b}$ shows the preferred restoration of Profile 3 . The Marginal High, the Gjallar Ridge and the Fles Fault Zone are restored close to sea level. The $\beta$-profile required to produce this restoration, assuming a Palaeocene-only rift model, is shown in Fig. 5c. $\beta$ reaches a maximum of 2.75 at the Gjallar Ridge and NW, diminishing to 1.6 at the Fles Fault Zone and 1.45 at the SE edge of the profile.

A forward model (not illustrated) of the syn-rift (Palaeocene) structure of Profile 3 has been constructed. The model included extension at the Vøring Marginal High and the Fles Fault Zone. The $\beta$-profile derived from this model is also shown (green) in Fig. 5c. Fault-controlled extension involves a maximum $\beta$ of $c$. 1.2, below both the Fenris Graben and the edge of the Rås basin. This forward modelled $\beta$-profile is much less than the $\beta$-profile of the simple backstripped model.

A third $\beta$-profile for Profile 3 is shown in Fig. 5c. It is the Palaeocene $\beta$-profile required to produce the restoration in Fig. $5 b$, assuming a $150 \mathrm{Ma}$ rift of $\beta=1.4$ and allowing for $460 \mathrm{~m}$ of plume-driven subsidence. The $\beta$-profile tapers from 1.75 , NW from the Gjallar Ridge, to 1.15 below the Fles Fault Zone, to 1.1 at the SE edge of the profile. In the NW the required $\beta$ remains in excess of the forward-modelled $\beta$, but at the Fles Fault Zone the required $\beta$ is similar to the forwardmodelled $\beta$. The implications of this are shown in Fig. $5 \mathrm{~d}$, backstripped to base Palaeocene using $\beta$ from the forward model and assuming a $150 \mathrm{Ma}$ rift $(\beta=1.4)$ and plume-driven subsidence. The Fles Fault Zone is restored to sea-level, but there is nearly $1 \mathrm{~km}$ of bathymetry above the Gjallar Ridge. We therefore have a similar conclusion to that derived for Profile 2, whereby in the SE of the profile our preferred forward and reverse models can be reconciled with a common value of $\beta$, but in the NW (nearer to the continental margin) the $\beta$ derived from backstripping is significantly greater than $\beta$ defined by upper-crustal extension. The $\beta$ of 1.75 required to restore the Gjallar Ridge is the largest required (given the preferred model parameters) on the three profiles, possibly because the Gjallar Ridge lies closer to the continental margin than the comparable Nyk High on Profiles 1 and 2.

\section{Model implications, a depth-dependent stretching model}

We have shown that we can backstrip our three profiles to yield geologically-plausible restorations (Figs 2b, 4b \& 5b). Our $\beta$ estimates derived from flexural backstripping are of similar magnitude to those derived using Airy backstripping by Skogseid et al. (1992b). We also know that we can produce accurate models of Palaeocene syn-rift structure, controlled by extensional faulting (Fig. 2d). Along the Fles Fault Zone/ Utgard High, c. $150 \mathrm{~km}$ landwards of the continental margin, the Palaeocene $\beta$ required for successful backstripping and the Palaeocene $\beta$ produced by forward modelling converge in a similar way to that in which forward and reverse modelled $\beta$ estimates from the North Sea converge (Roberts et al. 1993, 1995). Further to the NW, at the Nyk High and Gjallar Ridge, the $\beta$ required for backstripping is much greater than that produced by forward modelling. This observation has been made on all seven profiles (Fig. 1).

It could be argued that the discrepant extension estimates towards the margin arise either because unimaged 'sub-seismic' faults are contributing to upper-crustal extension (Walsh et al. 1991), or because we have underestimated the magnitude of plume-driven subsidence. If the discrepant extension were observed throughout the Vøring Basin this could be true, but the fact that our models converge at the Fles Fault Zone, and work also for the modelling of Jurassic extension on the Halten Terrace, leads us to suspect that we are observing the effect of a more local phenomenon than either of these two alternative explanations would imply. In addition sub-seismic faulting at most masks c. $35 \%$ of the total strain (Walsh et al. 1991), which would still not allow the two extension estimates to be reconciled. Furthermore the seismic data quality and fault definition in the basin are best in the Nyk High/Gjallar Ridge area where the misfit occurs. 


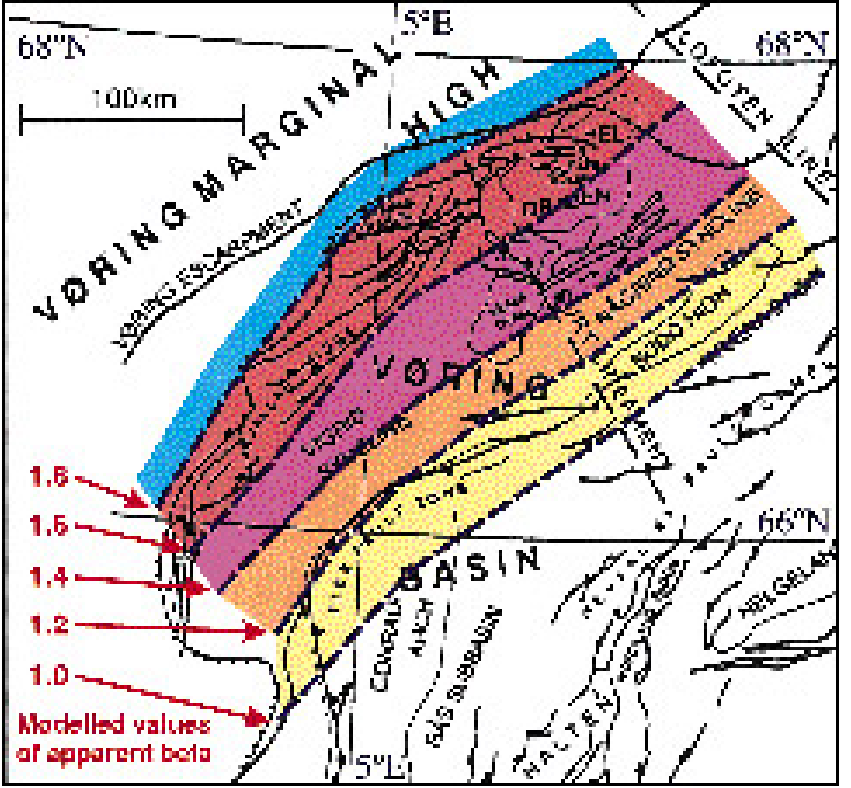

Fig. 6. Contoured map of Palaeocene 'apparent- $\beta$ ' in the Vøring Basin, derived from the preferred reverse models of the seven profiles in Fig. 1 (yellow $\beta$-profiles in Figs 2, 4 \& 5).

We believe the crucial observation to be that, even when possible buoyant underplating at the margin is ignored, the Palaeocene $\beta$ values derived from thermal subsidence by backstripping increase systematically towards the continental margin (Fig. 6), yet there is no corresponding increase in the upper-crustal strain. We propose the following model (Fig. 7) for the break-up of the margin to explain this.

In the early Palaeocene (c.65 Ma) the Vøring Basin, NW from the Fles Fault Zone, was stretched as an intra-continental rift. SE of the Marginal High (Fig. 1) this involved modest extension with maximum $\beta$ of $c .1 .2$ (forward models and Fig. 7a). Extension of this age is unimaged below the basalts of the Marginal High but did probably occur.

At the end of the Palaeocene (c. $57.5 \mathrm{Ma}$ ) continued or renewed extension below, and to the west of, the Marginal High led to continental separation. The normal faults associated with this final break-up have not yet been recognised. We suggest that within the plastic lower-crust and mantle some of the lithosphere stretching associated with break-up is partitioned landwards of the margin, below the outer part of the Vøring Basin, which did not undergo further upper-crustal extension at this time (Fig. 7b). We are thus proposing a two-layer stretching model (see Royden \& Keen 1980; Hellinger \& Sclater 1983) for the separation phase, with a strain discontinuity somewhere in the mid-crust. This model invokes greater thinning of the mantle lithosphere than of the crust. Thus our values of $\beta$ obtained from thermal subsidence by reverse modelling (assuming a uniform stretching model) (Fig. 6) are neither a true measure of crustal nor mantle lithosphere thinning. Thinning of the mantle lithosphere and lower crust will have been greater than the calculated $\beta$ and upper-crustal thinning will have been less. The mapped values of $\beta$ (Fig. 6) are therefore an 'apparent $\beta$ '. A consequence of the greater stretching at depth is to increase syn-rift thermal uplift by comparison with subsidence due to syn-rift crustal thinning, so reducing net syn-rift subsidence and possibly even giving rise to net syn-rift uplift. Our apparent $\beta$ measures the magnitude of geotherm perturbation during Palaeocene rifting
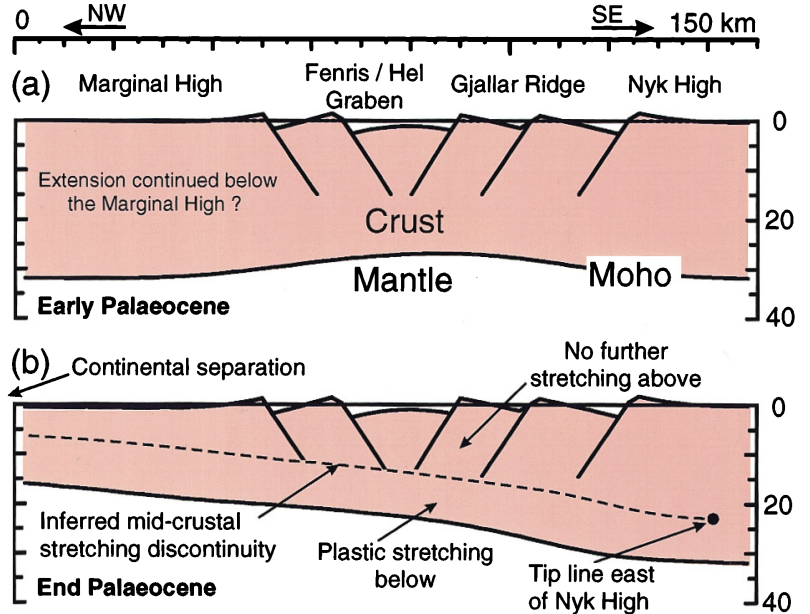

(c)

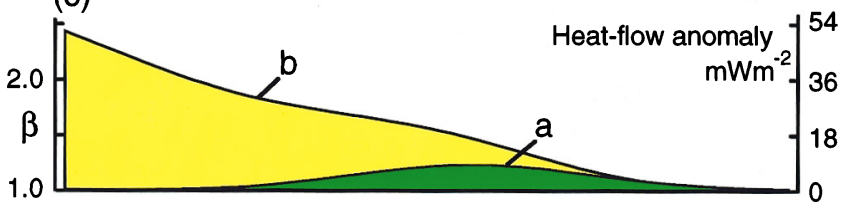

Fig. 7. Schematic model for the break-up of the Vøring margin. (a) Early Palaeocene rifting incorporating uniform stretching with depth and low $\beta$ factors (up to 1.2). Extension may have continued NW below the Marginal High. (b) Continental separation at the end of the Palaeocene. Lithosphere stretching below the Vøring Basin occurs only in the plastic lower crust and mantle. A strain discontinuity is inferred within the mid crust. Geotherm perturbation during this depth-dependent stretching inhibits syn-break-up subsidence, holding the Marginal High at sea-level, where sub-aerial basalts are extruded. Following break-up enhanced thermal subsidence commences. (c) $\beta$ and heat-flow anomalies relating to (a) and (b). Thermal modelling of the margin should use $\beta$ derived from flexural backstripping (b) and not that constrained by intra-basinal faulting alone (a).

and break-up (Fig. 7c), and therefore provides a better constraint on thermal modelling within the basin than $\beta$ determined from upper-crustal faulting. We reiterate that without the inclusion of underplating in our models our estimates of apparent $\beta$ are a likely minimum.

Anomalously large thermal subsidence has been documented adjacent to passive margins elsewhere, e.g. Chenet et al. (1983) at the Galicia margin and Westaway (1994) in the South China Sea. Both Chenet et al. and Westaway proposed the occurrence of excess lower-crustal stretching, by comparison with observable upper-crustal faulting. Other possible explanations for discrepant extension exist (e.g. Walker et al. 1997), but we believe that the increase in modelled $\beta$ towards the Vøring margin favours the long-wavelength distribution of plastic strain during continental separation.

We thank H. Kerr and an anonymous referee for helpful reviews, J. Skogseid both for his review and valuable discussion, and $\mathrm{G}$. Yielding for many discussions on stretching models. We are grateful to Statoil for permission to publish this work, the views expressed are, however, our own.

\section{References}

Chenet, P., Montadert, L., Gairaud, H. \& Roberts, D. 1983. Extension ratio measurements on the Galicia, Portugal and northern Biscay continental 
margins: implications for evolutionary models of passive continental margins. In: Watkins, J.S. \& Drake, C.L. (eds) Studies in continental margin geology. American Association of Petroleum Geologists Memoirs, 34, 703-715.

HaQ, B., Hardensol, J. \& Vail, P.R. 1987. Chronology of fluctuating sea level since the Triassic (250 million years to present). Science 25, 1156 1167.

Harland, W.B., Armstrong, R.L., Cox, A.V., Craig, L.E., Smith, A.G. \& Sмiтh, D.G. 1990. A Geologic Timescale 1989. Cambridge University Press.

Hellinger, S.J. \& Sclater, J.G. 1983. Some Comments on Two-Layer Extensional Models for the Evolution of Sedimentary Basins. Journal of Geophysical Research 88, 8251-8269.

KuszNIR, N.J. \& Egan, S.S. 1989. Simple-shear and pure-shear models of extensional sedimentary basin formation: application to the Jeanne d'Arc Basin, Grand Banks of Newfoundland. In: TANKard, A.J. \& BalKwill, H.R. (eds) Extensional Tectonics and Stratigraphy of the North Atlantic Margins. American Association of Petroleum Geologists Memoirs, 46, 305-322.

— \& Ziegler, P.A. 1992. The mechanics of continental extension and sedimentary basin formation: A simple-shear/pure-shear flexural cantilever model. Tectonophysics 215, 117-131.

—, Marsden, G. \& Egan, S.S. 1991. A flexural cantilever simple-shear/pureshear model of continental lithosphere extension: application to the Jeanne d'Arc Basin and Viking Graben. In: Roberts, A.M., Yielding, G. \& Freeman, B. (eds) The Geometry of Normal Faults. Geological Society, London, Special Publications, 56, 41-60.

—, Roberts, A.M. \& Morley, C. 1995. Forward and Reverse Modelling of Rift Basin Formation. In: Lambiase J. (ed.) Hydrocarbon Habitat in Rift Basins. The Geological Society, London, Special Publications, 80, 33-56.

Lundin, E.R. \& DoRÉ, A.G. 1997. A tectonic model for the Norwegian passive margin with implications for the NE Atlantic: Early Cretaceous to breakup. Journal of the Geological Society, London 154, 545-550.

Marsden, G., Yielding, G., Roberts, A.M. \& Kusznir, N.J. 1990. Application of a flexural cantilever simple- shear/pure-shear model of continental lithosphere extension to the formation of the northern North Sea. In: Blundell, D.J. \& GibBs, A.D. (eds) Tectonic Evolution of the North Sea Rifts. Oxford University Press, Oxford, 241-261.

McKenZIE, D.P. 1978. Some remarks on the development of sedimentary basins. Earth and Planetary Science Letters 40, 25-32.

Milton, N.J., Bertram, G.T. \& VanN, I.R. 1990. Early Palaeogene tectonics and sedimentation in the Central North Sea. In: Hardman, R.F.P. \& BrooKs, J. (eds) Tectonic Events Responsible for Britain's Oil and Gas Reserves. Geological Society, London, Special Publications, 55, 339-351.

NAdiN, P.A. \& KusZnIR, N.J. 1995. Palaeocene uplift and Eocene subsidence in the northern North Sea Basin from 2D forward and reverse stratigraphic modelling. Journal of the Geological Society, London 152, 833-848.

\& _ 1996. Forward and reverse stratigraphic modelling of CretaceousTertiary post-rift subsidence and Palaeogene uplift in the Outer Moray Firth Basin, central North Sea. In: KNox, R.W.O’B., CoRfIeld, R.M. \&
Dunay, R.E. (eds) Correlation of the Early Palaeogene in Northwest Europe. Geological Society, London, Special Publications, 101, 43-62.

RoberTs, A.M. \& Yielding, G. 1991. Deformation around basin-margin faults in the North Sea/Norwegian rift. In: Roberts, A.M., Yielding, G. \& Freeman, B. (eds) The Geometry of Normal Faults. Geological Society, London, Special Publications, 56, 61-78.

—, - Kusznir, N.J., Walker, I. \& Dorn-Lopez, D. 1993. Mesozoic extension in the North Sea: constraints from flexural backstripping, forward modelling and fault populations. In: PARKer, J.R. (ed.) Petroleum Geology of Northwest Europe: Proceedings of the 4th Conference. The Geological Society, London, 1123-1136.

$-,-1,-\_$\& — 1995. Quantitative analysis of Triassic extension in the Northern Viking Graben. Journal of the Geological Society, London, 152, 15-26.

Royden, L. \& Keen, C.E. 1980. Rifting process and thermal evolution of the continental margin of eastern Canada determined from subsidence curves. Earth and Planetary Science Letters 51, 343-361.

Skogseid, J. 1994. Dimensions of the Late Cretaceous-Palaeocene Northeast Atlantic rift derived from Cenozoic subsidence. Tectonophysics 240, 225247.

—, Pedersen, T., Eldholm, O. \& Larsen, B.T. 1992a. Tectonism and magmatism during NE Atlantic continental break-up: the Vøring Basin. In Storey, B.C., Alabaster, T. \& Pankhurst, R.J. (eds) Magmatism and the Causes of Continental Break-up. Geological Society, London, Special Publications, 68, 305-320.

— — \& LaRSen, V.B. 1992b. Vøring Basin: subsidence and tectonic evolution. In: LARSEN, R.M. ET AL. (eds) Structural and Tectonic Modelling and its Application to Petroleum Geology. Norwegian Petroleum Society Special Publications, 1, 55-82.

Walker, I.M., Berry, K.A., Bruce, J.R., BystøL, L. \& Snow, J.H. 1997. Structural modelling of regional depth profiles in the Vøring Basin: implications for the structural and stratigraphic development of the Norwegian passive margin. Journal of the Geological Society, London 154, $537-544$.

Walsh, J.J., Watterson, J. \& Yielding, G. 1991. The importance of small-scale faulting in regional extension. Nature 351, 391-393.

WATTS, A.B. \& TORNÉ, M. 1992. Crustal structure and the mechanical properties of extended continental lithosphere in the Valencia Trough (western Mediterranean). Journal of the Geological Society, London 149, 813-827.

Weissel, J.K. \& Karner, G.D. 1989. Flexural Uplift of Rift Flanks Due to Mechanical Unloading of the Lithosphere During Extension. Journal of Geophysical Research 94, 13 919-13 950.

Westaway, R. 1994. Re-evaluation of extension across the Pearl River Mouth Basin, South China Sea: implications for continental lithosphere deformation mechanisms. Journal of Structural Geology 16, 823-838.

YounG, R. 1992. Restoration of a regional profile across the Magnus Field in the Northern North Sea. In: LARSEN, R.M. ET AL. (eds) Structural and Tectonic Modelling and its Application to Petroleum Geology. Norwegian Petroleum Society Special Publications, 1, 221-229. 